\title{
The Information Content of Commercial Paper Rating Downgrades: Further Evidence
}

\author{
UDAY CHANDRA* \\ NANDKUMAR NAYAR**
}

\begin{abstract}
In this paper, we study the association between commercial paper rating downgrades and expectations of the level and variability of future earnings. Our examination shows that such rating downgrades are associated with a significant reduction in analyst forecasts of near-term earnings. We document a tendency by financial analysts at the Value Line Investment Survey to progressively revise their estimates of quarterly earnings downward on average and implement two methods to control for the resulting bias. The reduction in earnings estimates is robust to these controls. In addition, we observe an increase in systematic risk for a subset of firms for which the downgrade implies exit from the commercial paper market. Analysis of stock price changes around the downgrade announcement dates shows that although the information on lower future earnings reflected in mild rating downgrades merely confirms market beliefs, the information on lower level and/or higher variability of future earnings associated with severe downgrades constitutes new information unavailable to the market prior to the rating change announcement.
\end{abstract}

\section{Introduction}

There has been some controversy in the finance literature on the role of rating agencies in disseminating financial information to capital markets. Wakeman (1984) asserts that credit ratings reflect public assessment of bond risk with a lag

*School of Accounting, University of Oklahoma

**Finance Division, Price College of Business, University of Oklahoma

Nayar received financial support from the Noble Foundation, and the Cooksey and Laird Programs. Both authors also thank the University of Oklahoma Research Council for other financial assistance. Comments from William Kross, Byung Ro, Mike Rozeff, Gregory Waymire, and participants at the University of Oklahoma Accounting and Finance Joint Workshop are appreciated. Eli Bartov (referee) helped to focus and strengthen the paper considerably. Stephanie Farewell, Giri Iyer, Alex Lee, Lori Mason, Karen Nunez, and Scott Whisenant provided valuable research assistance. Address correspondence to the authors at Michael F. Price College of Business, Adams Hall, University of Oklahoma, Norman, OK 73019-0450, Tel: (405) 325-5591. 
and do not convey new information to the market. ${ }^{1}$ An alternative view is that rating agencies possess private information or superior processing ability with regard to public information so that their initial ratings and rating changes convey new information to the market. ${ }^{2}$

Consistent with the latter view, stock price reactions to rating changes for longterm instruments have been documented by Cornell, Landsman, and Shapiro (1989); Hand, Holthausen, and Leftwich (1992); Holthausen and Leftwich (1986); and Stickel (1986). More recently, Nayar and Rozeff (1994) investigated commercial paper (CP hereafter) issuances and rating changes and found that highly rated issuances are associated with positive stock price reactions. For rating changes, they report that downgrades produce negative stock returns, whereas upgrades have no effect.

Although evidence from prior research indicates that debt rating downgrades affect security prices, the nature of the information contained in the downgrades is unclear. If the rating downgrade conveys new information on the level of future earnings, this should also be reflected in a downward revision in earnings forecasts by security analysts. Additionally, if the rating change reflects information on increased variability of future earnings or cash flows, this should be incorporated into security prices as an increase in systematic risk.

Although these effects are applicable to rating changes on both long-term and short-term debt, there are two advantages to examining the latter. First, since shortterm debt matures at more frequent intervals, ratings on short-term debt are likely to be more closely scrutinized. Consequently, short-term debt rating changes may occur in a more timely fashion relative to those for longer-term securities, thereby providing a signal to investors of operational/business problems afflicting the downgraded firm. Second, since the interest rate charged on short-term debt is reset at each rollover of the maturing debt, the rating downgrade is likely to translate into higher borrowing costs faster for $\mathrm{CP}$ than for long-term debt. This is because for long-term debt, the firm has already locked in the interest rate at the time of initial issuance. Therefore, the impact of the $\mathrm{CP}$ rating change on interest costs may be reflected more quickly in earnings estimates relative to the effect of rating changes on long-term debt.

We document a significant reduction in earnings expectations around the downgrade announcement for both severely and mildly downgraded firms. ${ }^{3}$ This result is robust to adjustments made to account for the tendency of analysts to be

1. The function of a rating agency in Wakeman's framework is to "attest to the relative quality of the bond issue and to the accuracy of the accompanying information about the issuing company; and ... further monitor that bond's risk over the life of the bond." This avoids duplication of investor effort in assessing bond risk initially and in monitoring it continuously over time, thereby boosting the issue price of the bond.

2. Refer to Holthausen and Leftwich (1986) for evidence that a majority of industrial firms whose debt is rated by Standard and Poor's provide the agency with data that is not in the public domain such as detailed segment information and projected long-term financial statements.

3. Severe (mild) rating downgrades are those that (do not) imply exit of the firm from the commercial paper market. These terms are explained further in Section 3 of the paper. 
overoptimistic in their earlier earnings forecasts and to subsequently revise these downward over time. With regard to risk, our results indicate an increase in systematic risk (beta) for the subset of firms that were severely downgraded. Further, our results show that although the reduction in earnings expectations associated with mild downgrades is anticipated by the market prior to the rating change announcement, the increase in beta and/or lower expectations of future earnings associated with severe downgrades convey valuation-relevant information previously unavailable to the market.

The rest of this paper is organized as follows. Section 2 describes relevant characteristics of the CP market and discusses the hypotheses. In Section 3, the data sources are described. Section 4 reports the empirical methods employed and presents the results. Section 5 concludes the paper.

\section{The Commercial Paper Market and Implications of Downgrades}

Commercial paper is unsecured debt with a maturity of 270 days or less. ${ }^{4}$ Most $\mathrm{CP}$ is sold in large denominations either directly or through dealers. CP represents a lower cost alternative to bank loans for borrowing firms, with interest rates close to the risk-free rate. ${ }^{5}$ Generally, $\mathrm{CP}$ is rolled over on maturity or refinanced using longer-term debt by both financial and nonfinancial firms. Manufacturing firms sometimes use CP to finance their capital expenditures. Accounting rules permit such firms that roll over their CP continuously to carry CP on their balance sheets as long-term debt. Typically, $\mathrm{CP}$ is issued so as to be exempt from Securities and Exchange Commission registration requirements. ${ }^{6}$

The commercial paper market has grown in importance as a source of corporate short-term funds over the past 30 years. Abken (1981) reports that the number of firms issuing CP rose from over 300 in 1965 to about 1,000 in 1981. CP issuers rated by Moody's increased from under 800 in 1981 to approximately 1,900 in 1994 (Fons and Bergqwist [1994]). Rose (1985) estimates that the volume of CP outstanding grew from $\$ 124.4$ billion in 1980 to $\$ 245.3$ billion in 1985 . More recently, the Federal Reserve Bank of New York reported that CP outstanding in December 1991 amounted to $\$ 528$ billion, which implies a more than doubling of CP volume over a period of six years. ${ }^{7}$

The major purchasers of CP are money market mutual funds, corporations, insurance companies and banks, and state and local governments. In general, investors view $\mathrm{CP}$ holdings as secure investments with minimal default risk. Although $\mathrm{CP}$ is unsecured, $\mathrm{CP}$ investors achieve effective priority over purchasers of

4. Refer to Post (1992) for development and other details of the CP market.

5. Schnure (1994) reports an average three-month CP yield spread of 67 basis points over treasury bills over the period 1975-1993.

6. See Nayar and Rozeff (1994) for details on the exemption. [1994]).

7. Growth in dollar volume of CP leveled off during the period 1991-93 (Fons and Bergqwist 
secured obligations due to the very short term maturity of their claim, that is, CP holders expect to be paid before the firm goes bankrupt. However, for this de facto priority to hold, investors must buy the highest rated CP. Also, SEC regulations mandate that money market mutual funds (the largest buyers of $\mathrm{CP}$ ) can hold only the top rated $C P{ }^{8}$ As a result, only firms with the highest credit quality are able to issue CP. As with longer-term debt, issuers of CP frequently seek quality ratings for these obligations from rating agencies such as Standard and Poor's Corporation, Moody's Investors' Service, Duff and Phelps Rating Service, and Fitch Rating Services. Some rating agencies will rate CP programs even if they are not hired by the issuer to do so. ${ }^{9}$ The CP ratings fall into several categories. Higher ratings are A1+, A1 (Standard \& Poor's), or Prime 1 (P1) (Moody's), whereas lower ratings are $\mathrm{A} 2$ and Prime 2 (P2). Issuers rated even lower, A3, Prime 3 (P3), or Not Prime, generally find that they cannot issue $\mathrm{CP}$, and most outstanding $\mathrm{CP}$ lies in the top categories. ${ }^{10}$

Although there is a strong association between long-term and short-term credit ratings, long-term creditworthiness does not fully measure access to the CP market. In other words, it is possible for firms to have the same long-term bond ratings but different $\mathrm{CP}$ ratings. In assessing the quality of $\mathrm{CP}$, rating agencies consider the ability of a company to deal with unexpected financing needs, such as the inability to roll over maturing CP. This is critical as due to the short, fixed maturity profile of $\mathrm{CP}$, most companies would be unable to repay maturing $\mathrm{CP}$ at short notice from internally generated cash. Calomiris et al. (1995) show that holding bond ratings constant, access to the CP market is enhanced by large firm size, high collateral, high earnings, low earnings variance, and large stocks of liquid assets.

$\mathrm{CP}$ rating downgrades are observed to cause "orderly exit" from the CP market (Fons and Kimball [1992]). Specifically, the market for an issuer's CP dries up after a rating downgrade, which leads to a reduction in the amount of CP outstanding. ${ }^{11}$ If the default risk becomes considerable, the firm is unable to sell its CP by

8. The relevant SEC regulation (Rule 2A-7) was implemented in 1991, which occurs during the sample period for this study. Refer to Schnure (1994) for reasons other than Rule 2A-7 for the reluctance of money market mutual funds to hold lower rated $\mathrm{CP}$ and the view that this regulation merely codified informal standards that had previously guided their CP purchases.

9. Refer to Cantor and Packer (1995) for details.

10. Stigum (1983, p. 637) states that CP "rated A3 and P3 is salable only to very few investors." Abken (1981) reports that for mid-1980, 75 percent of outstanding CP was in grade 1, 24 percent in grade 2, and only 1 percent in grade 3 and below. More recently, Fons and Bergqwist (1994) note that of all the CP outstanding that was rated by Moody's on September 30, 1993, 86 percent was Prime-1, 13 percent was Prime-2, 0.8 percent was Prime-3, and 0.04 percent was rated Not Prime. This data shows that markets for CP rated Prime-3 or worse are narrow or nonexistent.

11. Fons and Bergqwist (1994) report that for $430 \mathrm{CP}$ rating downgrades that occurred between 1972 and 1989, CP outstandings declined by 28 percent when the downgrade was to $P 2$ and by 63 percent $(83 \%)$ when the downgrade was to P3 (NP) over a half-year period surrounding the downgrade announcement. Presumably, the volume in the lowest category would disappear if the amount outstanding was followed further out in time. Furthermore, Crabbe and Post (1994) find that downgrades of bank holding company CP ratings lead to significant reductions in the amounts of CP outstanding. Moreover, the volume of CP outstanding in the third grade and below has historically hovered in the 1 percent range (see previous footnote). Thus, a downgrade to the third category or lower implies a forced exit from the CP market. 
offering a higher interest rate. It is instead forced to withdraw from the CP market and to retire its $\mathrm{CP}$ through funds generated via other, more expensive financing or asset sales. This "orderly exit" tends to occur prior to any default on the firm's long-term debt and keeps the default rate of CP (less than 0.05 percent on average) considerably below that for long-term debt.

It is clear from the preceding discussion that investors view their CP holdings as "near-cash" and tend to buy CP only of firms with high, stable earnings. Rating agencies stake their reputations on their ratings since a prime rating implies that a firm's CP will be paid on time even if it is subsequently downgraded (Fons and Bergqwist [1994]). We hypothesize that a perceived decrease in level of earnings and/or increase in its riskiness will prompt rating agencies to downgrade a firm's $\mathrm{CP}$. If the information conveyed by rating downgrades signals reduced levels of earnings, then we expect that financial analysts will lower their earnings estimates for downgraded firms. Also, if rating changes contain information about the riskiness of future cash flows, this should be reflected in a change in systematic risk (beta) of downgraded firms. ${ }^{12}$ Consequently, to study the information content of CP downgrades, we examine changes in analysts' forecasts of contemporaneous and future earnings, and systematic risk.

Several prior studies have examined firm-specific earnings forecast revisions and risk changes subsequent to other major corporate events. For example, Hertzel and Jain (1991) develop an analytical model that decomposes security price changes into changes in levels and riskiness of future earnings, and proceed to test it for stock repurchase tender offer announcements. ${ }^{13}$ They find that short-term earnings forecasts are revised upward (consistent with the positive stock price reaction that accompanies stock repurchase announcements), and equity betas decline. Ofer and Siegel (1987) investigated analyst responses to dividend changes and found that earnings forecasts are revised upward, consistent with an information signaling role for dividends. Bartov (1991) examined the market reaction to open market share repurchase announcements, and found that they are associated with upward revisions in analyst earnings forecasts and declines in equity betas for the repurchasing firms. More recently, Shastri and Shastri (1995) examined earnings forecast revisions and risk changes associated with announcements of calls of convertible preferred stocks. They do not find any significant revisions in earnings forecasts, even though such announcements are associated with a negative stock price reaction. Given their evidence, Shastri and Shastri (1995) conclude that announcements of calls of convertible preferred stock do not convey information about future cash flows. In a similar vein, we attempt to determine whether CP rating downgrades convey information about future cash flows of the affected firms by examining changes in earnings expectations and equity betas.

12. Refer to Beaver, Kettler, and Scholes (1970) for evidence of a positive association between beta and earnings variability.

13. Our use of beta as a proxy for the variability of future earnings is consistent with Hertzel and Jain (1991). 


\section{Data}

The data on CP rating downgrades used in this study was obtained from weekly issues of Moody's Bond Survey (MBS) beginning in 1977 and ending in December 1994. The sample is limited to CP rating changes that are unaccompanied by rating changes of any other security like bonds, preferred stock, and the like. We excluded the latter observations because inclusion of firms that experience concurrent rating changes on other securities may contaminate our results, given our exclusive focus on $\mathrm{CP} .^{14}$

In the $\mathrm{CP}$ market, $\mathrm{CP}$ rated $\mathrm{P} 1$ or $\mathrm{P} 2$ is highly marketable, whereas $\mathrm{CP}$ rated $\mathrm{P} 3$ or Not Prime is not. In this respect, the rating downgrade from P2 to P3 effectively becomes a proxy for termination of a $\mathrm{CP}$ program or a substantial reduction in its volume. Our rating change sample contains 56 downgrades from P1 to P2 and 41 downgrades from P2 to P3 or lower (Not Prime) for a total of $97 \mathrm{CP}$ downgrade events. Consistent with Nayar and Rozeff, we define a variable, DEG, to measure the severity of the downgrade. DEG takes on a unit value when the downgrade is from P2 to P3 or worse, and a value of zero for a change from P1 to $\mathrm{P} 2$. We refer to the former as a severe downgrade, whereas the latter is defined to be a mild downgrade. Earnings forecast data on dates before and after the rating changes were obtained from various issues of the Value Line Investment Survey. Common stock returns were obtained from the CRSP database and financial statement data are from Compustat.

Table 1 provides descriptive statistics on the sample of firms experiencing $\mathrm{CP}$ downgrades. ${ }^{15}$ Firms with $\mathrm{CP}$ programs tend to be larger and more creditworthy than typical firms. For a detailed comparison of firms that do and do not issue CP, the reader is referred to Calomiris, Himmelberg, and Wachtel (1995).

\section{Empirical Methods and Results}

\subsection{Earnings Forecast Revisions}

For each firm in the sample, earnings forecasts made by analysts at the Value Line Investment Survey (VL) on dates immediately before, $b$, and after, $a$, the rating downgrade were compiled. The time line in Figure 1 shows the various points in time relevant in computing earnings forecast revisions. Specifically, we collected the forecasts for the two earliest quarters, $q 1$ and $q 2$, for which earnings had not been announced on $a$, the date of the first issue of Value Line published after the downgrade that contained the firm's earnings fore-

14. A portion of the data used in this study was collected for Nayar and Rozeff (1994). We thank them for providing us with this data.

15. For Table 1, several firms had missing data. This was because financial data on these firms were (1) unavailable from Compustat and/or (2) they were utilities or financial firms. 
TABLE 1

\section{Descriptive Statistics for the Sample of Firms Experiencing a Pure Commercial Paper Rating Downgrade}

The sample of pure commercial paper downgrades was obtained from issues of Moody's Bond Survey from 1986 to 1994. The statistics here are obtained for the sample firms from the Compustat primary, secondary, and tertiary, full coverage, and research files. The numbers are taken from the financial statements in the fiscal year immediately preceding the rating downgrade.

\begin{tabular}{lcccccc}
\hline Measure & $\begin{array}{c}\text { Number of } \\
\text { Observations }\end{array}$ & Mean & Median & Minimum & Maximum & $\begin{array}{c}\text { Standard } \\
\text { Deviation }\end{array}$ \\
\hline $\begin{array}{c}\text { Total assets } \\
\text { (million \$) }\end{array}$ & 77 & 2109.9 & 1368.6 & 161.9 & 12417.5 & 2139.6 \\
$\begin{array}{c}\text { Current ratio } \\
\begin{array}{c}\text { Market value } \\
\text { of common }\end{array}\end{array}$ & 71 & 1.78 & 1.75 & 0.42 & 3.39 & 0.56 \\
$\begin{array}{c}\text { equity (mil- } \\
\text { lion \$) }\end{array}$ & 77 & 798.0 & 564.0 & 37.5 & 5963.8 & 895.3 \\
$\begin{array}{c}\text { Debt ratio } \\
\text { Den }\end{array}$ & 70 & 0.225 & 0.210 & 0.008 & 0.641 & 0.114
\end{tabular}

-Current ratio is the ratio of current assets to current liabilities.

${ }^{b}$ Debt ratio is computed as (short-term debt + long-term debt)/total assets.

casts. ${ }^{16}$ Let $F_{b q 1}$ be the forecast made on date $b$ (i.e., before the rating change occurs) of earnings to be realized at the end of the next fiscal quarter ( $q 1)$. Similarly, let $F_{b q 2}$ represent the forecast made on date $b$, prior to the rating downgrade, of earnings for the second fiscal quarter $(q 2)$. Next, let $F_{a q 1}$ and $F_{a q 2}$ be the forecasts made on date $a$, that is, after the rating downgrade has occurred, of the earnings to be realized at the first $(q 1)$ and second $(q 2)$ fiscal quarter-ends, respectively. ${ }^{17}$

For example, say that a rating downgrade occurred in October 1982 for a firm with a December 31 fiscal year-end. For this firm, say that the earnings forecasts appear in the August 23 and November 22, 1982, issues of Value Line. Then $F_{b q 1}$ $\left(F_{b q 2}\right)$ refers to the forecast that appears in the August 23, 1982, Value Line issue, whereas $F_{a q 1}\left(F_{a q 2}\right)$ refers to the forecast in the November 22, 1982, issue regarding earnings for the quarter ending December 31, 1982 (March 31, 1983), if actual third-quarter earnings are reported in the November 22 issue of VL. ${ }^{18}$

16. Value Line analyzes the performance of a subset of firms each week, with each firm being covered once per quarter. A source at VL informed us that eamings forecasts reported in VL are made exactly seven days before the date stamped on the issue, which is the approximate date at which it is received by subscribers. Dates $a$ and $b$ were selected after adjusting for this reporting lag. We did not examine long-range earnings forecasts as these tend to be fairly stable in the presence of information on potential earnings changes. A possible explanation for this phenomenon may be that analysts are reluctant to revise their long-range forecasts early due to the possibility that new information may render the revision unnecessary (Stickel [1989]).

17. In the material that follows, these and other variables are computed for every downgrade event in the sample. For notational simplicity, we have chosen to omit the event subscript.

18. If actual third-quarter earnings are not reported in the November 22 issue of VL, then $q 1$ and $q 2$ refer to the quarters ended September 30 and December 31,1982 , respectively. 


\section{FIGURE 1}

\section{Time Line to Illustrate the Sequence of Dates for Earnings Forecast Revision Tests}

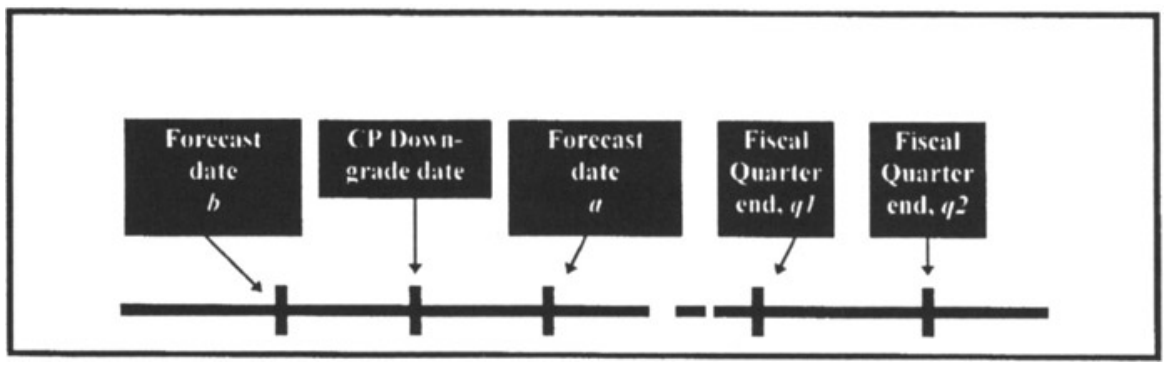

The difference in earnings forecasts made before and after the downgrade was scaled by $P_{b}$, the predowngrade stock price. ${ }^{19}$ Specifically, the following terms were computed for each event in our sample:

$$
\delta_{q 1}=\left(F_{a q 1}-F_{b q 1}\right) / P_{b} \text { and } \delta_{q 2}=\left(F_{a q 2}-F_{b q 2}\right) / P_{b} .
$$

In eq. (1), $\delta_{q_{1}}$ and $\delta_{q_{2}}$ represent revisions in the VL forecasts for quarters $q 1$ and $q 2$ around disclosures of the rating downgrades. Under the null hypothesis of no systematic change in analyst forecasts around the rating downgrade, the average of these forecast changes should be close to zero. Parametric $t$ tests were conducted on $\delta_{q 1}$ and $\delta_{q 2}$ to see if their means are negative. A nonparametric Wilcoxon signed rank test was also used.

The use of $\delta_{q 1}$ and $\delta_{q 2}$ as proxies for changes in market expectations of earnings may bias our test results in view of the statistical properties of analysts' forecasts documented in prior research. O'Brien (1988) reports a negative bias in mean earnings forecast errors for forecasts of annual earnings made by analysts from different brokerage houses. ${ }^{20}$ Francis and Philbrick (1993) document an average optimism of 9 percent of forecasted earnings ( $\$ 0.18$ per share) in a sample of Value Line forecasts of annual and first-quarter earnings. Furthermore, Stickel (1990) using data on annual earnings forecasts made by a large cross section of analysts shows that, on average, the optimism in an analyst's forecasts reduces with each successive forecast. If this successive reduction in optimism extends also to Value Line forecasts of quarterly earnings, the measures of change in market expectations defined in eq. (1) would bias our statistical tests toward rejection of the null hy-

19. $P_{b}$ (from Value Line) is the firm's stock price two days before forecast date $b$.

20. Possible reasons for the systematic optinism in analysts" forecasts that have been mentioned in prior research are (a) analysts' desire to maintain good relations with management, (b) failure to fully incorporate recent negative earnings into their forecasts, and (c) incentives associated with their firms' brokerage, underwriting and investment banking activities (see O'Brien [1988] and Francis and Philbrick [1993], for example). Our use of Value Line may mitigate some of these concerns since Value Line is not engaged in the brokerage/underwriting business. 
TABLE 2

\section{Descriptive Statistics and Tests on Measures of Differential Bias in Successive Value Line Forecasts of Quarterly Earnings}

\begin{tabular}{lccccc}
\hline Measure & $\begin{array}{c}\text { Number of } \\
\text { Observations }\end{array}$ & Mean & Median & t Statistic & Signed Rank \\
\hline$\Sigma q_{1}$ & 91 & -0.00217 & -0.00062 & $-2.60^{* *}$ & $-498.0^{* *}$ \\
$\Sigma q_{2}$ & 88 & -0.00134 & -0.00014 & $-2.29^{* *}$ & $-490.0^{* * *}$
\end{tabular}

$\Sigma_{q 1}$ and $\Sigma_{q 2}$ denote changes in the one- and two-quarter-ahead earnings forecasts estimated in the year prior to the event year. They represent the expected reduction in forecasted earnings over a quarter due to the tendency of analysts to be more optimistic about earnings over longer forecast horizons.

* Significantly different from 0 at the 0.05 level in a one-tailed test.

** Significantly different from 0 at the 0.01 level in a one-tailed test.

*** Significantly different from 0 at the 0.001 level in a one-tailed test.

pothesis of no reduction in forecasts of future earnings. To filter out this bias from our analysis, we define proxies for the expected forecast revision over the period between the two VL forecast dates $b$ and $a$ by computing earnings forecast revision measures analogous to $\delta_{q 1}$ and $\delta_{q 2}$ for each event over corresponding windows in the year prior to the event year. ${ }^{21}$ These measures, denoted by $\Sigma_{q 1}$ and $\Sigma_{q 2}$, respectively, are used as proxies for the expected forecast revisions due to reduction in optimistic bias over successive analysts' forecasts absent the release of any information on the firm's earnings over the intervening period. In Table 2, we present descriptive statistics on $\Sigma_{q 1}$ and $\Sigma_{q 2}$ and associated test results.

In Table 2, over the period corresponding to the event period in the year prior to the event year, the mean Value Line forecast revision was -0.22 percent of stock price for quarter $q 1$ and -0.13 percent of stock price for the following quarter. The parametric $t$ test indicates that the mean forecast revision is statistically significant for both quarters. The nonparametric test confirms these results. ${ }^{22}$ This suggests that VL analysts systematically lower their earnings estimates over successive forecasts for the same firm-quarter. This result is consistent with Stickel (1990) who reports a significant downward drift in annual earnings forecasts for

21. With reference to our earlier example of an event date in October 1982, we would now compute measures of earnings forecast revisions [refer to eq. (1)] using forecasts made in the relevant Value Line issues from August and November 1981. We also used data from a year after the event to measure the expected reduction in forecast optimism. These results are qualitatively similar to those obtained using data from the year prior to the event and are not reported.

22. We also tested for the presence of this bias using a larger sample of firms, that is, not just those with rating changes. Specifically, we extracted the Value Line forecasts for all firms available on the Zacks detailed earnings estimates tapes in the period from 1984 through 1994. For these Value Line estimates, we computed measures analogous to the variables $\Sigma_{q 1}$ and $\Sigma_{q 2}$ and tested to see if they, in general, were different from 0 . The results using 38,838 observations for $\Sigma_{q 1}$ and 18,275 observations for $\Sigma_{q^{2}}$ indicate that both the first- and second-quarter-ahead forecast revisions are negative and significant, with the latter being smaller in magnitude. These results are qualitatively similar to those for our $\mathrm{CP}$ downgrade sample. 
sell-side analysts. Thus, the differential optimism in consecutive analysts' forecasts of quarterly earnings needs to be controlled for when using such forecast revisions as proxies for changes in market expectations of future cash flows associated with potentially informative events.

In our study, we introduce such a control by determining an adjusted revision in market expectations of earnings for each event, which is computed as $\delta_{q 1}$ and $\delta_{q 2}$ minus the respective expected forecast revisions represented by $\Sigma_{q 1}$ and $\Sigma_{q 2}$. Specifically, we compute

$$
\Omega_{q 1}=\delta_{q 1}-\Sigma_{q 1} \text { and } \Omega_{q 2}=\delta_{q 2}-\Sigma_{q 2}
$$

One can think of $\Omega_{q 1}$ and $\Omega_{q 2}$ as the unexpected components of earnings forecast revisions scaled by price for $q 1$ and $q 2$. The adjustment already described is aimed at filtering out the tendency of analysts to be overoptimistic in their early forecasts and then to progressively reduce their earnings estimates with the passage of time. Our adjustment procedure generates a unique value for the expected forecast revision around each event and controls for its variation by firm, analyst, financial quarter, and forecast horizon in the aggregate. ${ }^{23}$

Statistical tests previously conducted on $\delta_{q 1}$ and $\delta_{q 2}$ are also performed on the measures computed using eq. (2), that is, after adjustment for the optimistic bias in analysts' forecasts of earnings. The results of the tests on $\delta$ and $\Omega$ appear in Table 3. In the first and third rows, for the first fiscal quarter-end subsequent to the rating downgrade, both measures of earnings forecast revisions (i.e., unadjusted, represented by $\delta_{q 1}$, and adjusted for changes in analysts' optimistic bias, represented by $\Omega_{q 1}$ ) are negative on average and significant for the full sample (panel A). This finding is robust to whether the parametric or the nonparametric test is employed. The results in the second and fourth rows of panel $A$ indicate that the revision in earnings forecasts for the second fiscal quarter-end after the rating downgrade, both unadjusted and adjusted for differences in analyst forecast bias, is also negative and significant. However, this effect is not as strong as its counterpart for the first fiscal quarter-end. Thus, on average, there is a significant downward revision in earnings forecasts for both the first and second fiscal quarter-ends subsequent to the rating downgrades.

To assess the pervasiveness of the association between CP rating downgrades and earnings forecast revisions, we partition our sample events on the severity of the downgrade and recompute the four measures of earnings forecast revision shown in panel $A$ of Table 3 for these subsamples. The results are presented in panel B (C) of Table 3 for the severe (mild) downgrade subsamples. The downward revision in analyst earnings forecasts for the overall sample does not appear to be

23. Ideally, we would have liked to arrive at our firm-specific estimates of expected reduction in analyst optimism by aggregating forecast data over several years, thereby reducing noise. However, since our data was manually collected from issues of Value Line, $\Sigma_{q 1}$ and $\Sigma_{q 2}$ are obtained in this study. using only one previous value of forecast revision for each event. Later in this section, we describe and present results for an alternative method that compares the earnings forecast revisions for the treatment firms against those of control firms. 
TABLE 3

\section{Earnings Forecast Revisions for Firms around Commercial Paper Rating Downgrades-Raw and Adjusted for Analyst Forecast Bias}

The sample of firms with a commercial paper downgrade was obtained from Moody's Bond Survey from 1986 to 1994. Earnings forecasts were obtained from the Value Line Investment Survey. The subscripts $q 1$ and $q 2$ in the variables refer to the one and two fiscal quarter ends subsequent to the commercial paper rating change announcement; $\delta$ represents the earnings forecast revision over the rating change period deflated by the predowngrade stock price; and $\Sigma(\Omega)$ denotes the standardized forecast revision $\delta$ adjusted for analyst forecast bias by using one-year-before (matched firm) forecast revisions.

\begin{tabular}{|c|c|c|c|c|c|}
\hline $\begin{array}{l}\text { Forecast } \\
\text { Revision } \\
\text { Measure }\end{array}$ & $\begin{array}{c}\text { Number } \\
\text { of } \\
\text { Observations }\end{array}$ & Mean & Median & t Statistic & $\begin{array}{c}\text { Signed } \\
\text { Rank }\end{array}$ \\
\hline \multicolumn{6}{|c|}{ Panel A: Full sample } \\
\hline$\delta_{q 1}$ & 91 & -0.00995 & -0.00333 & $-4.07 * * *$ & $-931.5^{* * *}$ \\
\hline$\delta_{q 2}$ & 88 & -0.00404 & -0.00277 & $-3.82 * * *$ & $-687.5^{* * *}$ \\
\hline$\Omega_{Q 1}$ & 91 & -0.00778 & -0.00280 & $-3.24 * * *$ & $-740.0^{* * *}$ \\
\hline$\Omega_{q 2}$ & 88 & -0.00270 & -0.00155 & $-2.16^{*}$ & $-487.5^{* *}$ \\
\hline$\psi_{q 1}$ & 90 & -0.00790 & -0.00196 & $-2.97 * *$ & $-772.5^{* * *}$ \\
\hline$\psi_{q 2}$ & 85 & -0.00124 & -0.00012 & -1.14 & -185.5 \\
\hline \multicolumn{6}{|c|}{ Panel B: Severe downgrade subsample } \\
\hline$\delta_{q 1}$ & 37 & -0.01301 & -0.00471 & $-2.75^{* *}$ & $-152.0^{* k *}$ \\
\hline$\delta_{q 2}$ & 35 & -0.00425 & -0.00071 & $-2.02 *$ & $-75.0^{*}$ \\
\hline$\Omega_{q 1}$ & 37 & -0.01002 & -0.00308 & $-2.17^{*}$ & $-115.0^{*}$ \\
\hline$\Omega_{q 2}$ & 35 & -0.00262 & -0.00133 & -1.20 & -42.5 \\
\hline$\psi_{q 1}$ & 36 & -0.01099 & -0.00216 & $-2.41^{*}$ & $-198.5^{* * *}$ \\
\hline$\psi_{42}$ & 32 & -0.00081 & -0.00009 & -0.45 & -14.5 \\
\hline \multicolumn{6}{|c|}{ Panel $C$ : Mild downgrade subsample } \\
\hline$\delta_{q 1}$ & 54 & -0.00785 & -0.00293 & $-3.08 * *$ & $-317.5^{* * *}$ \\
\hline$\delta_{q 2}$ & 53 & -0.00390 & -0.00313 & $-3.57^{* * *}$ & $-321.0^{* * *}$ \\
\hline$\Omega_{q 1}$ & 54 & -0.00624 & -0.00230 & $-2.46^{* *}$ & $-271.5^{* *}$ \\
\hline$\Omega_{q 2}$ & 53 & -0.00275 & -0.00176 & $-1.83^{*}$ & $-230.5^{* *}$ \\
\hline$\psi_{q 1}$ & 54 & -0.00583 & -0.00078 & $-1.80^{*}$ & -171.0 \\
\hline$\psi_{a z}$ & 53 & -0.00150 & -0.00012 & -1.09 & -95.0 \\
\hline
\end{tabular}

* Significantly different from 0 at the 0.05 level in a one-tailed test.

** Significantly different from 0 at the 0.01 level in a one-tailed test.

*** Significantly different from 0 at the 0.001 level in a one-tailed test.

driven by observations in either the severe or mild downgrade subsample. We also conducted parametric and nonparametric tests on $\delta$ and $\Omega$ to determine any differences of location in earnings forecast revisions between the two subsamples. These tests did not reveal a significant difference in the magnitude of forecast revisions between the two subsamples. In other words, both mild and severe downgrades of 
$\mathrm{CP}$ ratings are associated with downward revisions in market expectations of shortterm earnings. ${ }^{24}$

The use of $\Omega$ as the measurement variable for earnings forecast revision is based on the assumption that the analyst bias is stationary, that is, the bias around the event date is the same as that in the prior year. As a robustness check, we also used an alternate measure to adjust for analysts' optimistic bias. In this alternative method, for each sample firm, we identify a control firm (followed by Value Line) in the same industry and closest in size to our sample firm as measured by net sales prior to the downgrade announcement. ${ }^{25}$ Since earnings forecasts for all firms in the same industry are made by Value Line in a single issue, the forecast dates for each sample firm and its matched control firm are identical. For these control firms, we compute variables analogous to $\delta_{q 1}$ and $\delta_{q 2}$, which we define to be $\delta_{q 1, m}$ and $\delta_{q 2, m}$. We then compute the unexpected revision in earnings forecast for the sample firm (i.e., after adjusting for the control firm's earnings forecast revision) as

$$
\psi_{q 1}=\delta_{q 1}-\delta_{q 1, m} \text { and } \psi_{q 2}=\delta_{q 2}-\delta_{q 2, m}
$$

where the subscript $m$ denotes the matched firm. Apart from filtering out analyst bias, this method also controls for industry-specific and economywide information (implicit in the control firm's forecast revisions) entering the market during the forecast revision period. However, if the downgrade of a firm's CP causes analysts to lower the earnings expectations for other firms in the same industry, that is, if intraindustry information transfers are occurring, this method would bias our test results against rejection of the null hypothesis by screening out a portion of the treatment effect. ${ }^{26}$

After the computation of $\psi_{q 1}$ and $\psi_{q 2}$, parametric and nonparametric statistical tests (as used for $\delta$ 's) were conducted. The results are also shown in Table 3 as additional rows in each of panels $\mathrm{A}, \mathrm{B}$, and $\mathrm{C}$. These results confirm the results described earlier for the one-quarter-ahead earnings forecast revisions. They are significantly negative for the full sample as well as for both the severe and mild

24. We also conducted multiple regressions using various measures of earnings forecast revision as the dependent variable and the variables DEG (an indicator variable that equals 0 [1] for mild [severe] downgrades), the three-day abnormal return over days $[-2,0]$ relative to the $C P$ downgrade announcement date, the multiday abnormal return over $[b, a]$ not including $[-2,0]$, and the amount of long-term debt as a fraction of total assets as of the last fiscal year-end before the downgrade as independent variables. None of the regression coefficients were significant.

25. A benefit of this matching mechanism is that we avoid the problems of matching on SIC codes noticed by Kahle and Walkling (1996). Additionally, refer to Ramnath (1996) for evidence that grouping firms based on analyst following rather than by four-digit SIC codes results in a more homogeneous set of firms.

26. Refer to Foster (1981) for evidence that surprises associated with earnings releases of a firm are related to contemporaneous security price changes for other firms in the same industry and to Baginski (1987) for evidence that announcements of management forecasts of firm-specific earnings are associated with security price changes of other industry members. An examination of whether or not $\mathrm{CP}$ rating downgrades are associated with such intraindustry information transfers is beyond the scope of this paper. 
downgrade subsamples. The second-quarter-ahead forecast revisions are also negative, albeit insignificant. As before, we also conducted difference of location tests between the two subsamples according to severity of the downgrade. The results of these tests did not indicate any statistical difference in the earnings forecast revisions between the severe and mild downgrade subsamples.

The downward revisions in earnings forecasts documented in Table 3 can be viewed as arising from two possible sources. ${ }^{27}$ First, this may primarily reflect expectations of an increase in the future interest expense of the firm due to the $C P$ downgrade. Second, the market may additionally interpret the rating downgrade as a signal of lower operating performance for the firm beyond the likely increase in interest expense induced by the downgrade. To provide some insight into this issue, we examined sales forecast revisions by Value Line analysts across the CP downgrade date. We selected sales as our variable of interest as (1) interest expense is not directly related to sales revenues and (2) it is the only other income statement item, apart from earnings, for which Value Line issues quarterly forecasts. We find that the percentage revision in sales forecasts is negative on average and significant for the first fiscal quarter-end subsequent to the downgrade. For the second fiscal quarter-end, the revision is negative but only marginally significant. ${ }^{28}$ These results suggest that the information conveyed by $\mathrm{CP}$ rating downgrades is associated with lower future sales prospects. Furthermore, they support the hypothesis that the downward revision in earnings forecasts associated with rating downgrades reflects expectations of lower operating performance beyond increased borrowing costs induced by the downgrade.

\subsection{Risk Shifts}

To test for shifts in beta around $\mathrm{CP}$ rating downgrade announcements, stock returns for each firm and the CRSP equally weighted market index are collected over two separate time windows. The first window (designated "preevent") consists of a 250 trading day period ending on day -51 in event-time (where day 0 is the day of the announcement of the downgrade). The second window ("postevent") is also 250 trading days in length but begins on day +51 in event time. The following system of equations is estimated over the entire 500 trading day period in event time:

$$
R_{\mathrm{it}}=\alpha_{i}+\beta_{i} R_{M t}+\lambda_{i} R_{M t} D_{i s}
$$

27. We thank the referee for suggesting these possibilities for investigation.

28. For the first fiscal quarter end, the mean revision in sales forecasts over 91 sample downgrades was -2.4 percent with a $t$ statistic of -2.02 (significant at the 0.05 level in a one-tailed test) and a Wilcoxon signed rank statistic that was significant at the 0.01 level. The test relating to the second fiscal quarter-end was conducted over 88 observations and produced a mean revision in sales forecasts of -1.7 percent, with a $t$ statistic of -1.46 (insignificant) and a Wilcoxon signed rank test statistic significant at the 0.01 level. 
where $t=-300,-299, \ldots,-51,+51,+52, \ldots,+300$, (a day index) and $i=$ $1,2, \ldots, N$ (an event index). In eq. (4), $R_{i t}$ is the return on day $t$ for security $i$; $R_{M t}$ is the equally weighted market retum on day $t ; D_{i t}$ is a dummy variable that equals 1 in the postevent period and is 0 before it; and $\alpha_{i}, \beta_{i}$, and $\lambda_{i}$ are eventspecific regression coefficients. The coefficient $\lambda_{i}$ represents the change in beta after the rating downgrade. The joint estimation and hypothesis testing provides us with a powerful test for examining whether beta has changed, on average, after the $\mathrm{CP}$ rating downgrade across all firms in the sample. If rating downgrades are associated with a perception of higher risk for the affected firms' securities, $\lambda_{i}$ should be positive on average.

The results of the estimation for the downgraded firms are presented in panel A of Table 4. These results indicate that for the overall sample (sufficient security return data was available on CRSP for 83 downgrade events), beta increased by 0.055 from an average of 0.94 . This increase is statistically significant at the 0.05 level. Thus, for the overall sample, an increase in risk is detected. Following this test on the overall sample, separate tests are then conducted on the two subsamples formed on severity of the downgrade. For the severe downgrade sample, the mean beta change is 0.110 , which is significantly positive at the 0.05 level in a one-tailed test. On the other hand, for the mild downgrade sample, the mean $\lambda_{i}$ is insignificant. This implies that only firms with a severe CP downgrade experience a significant increase in their systematic risk. ${ }^{29}$

One reason for the documented beta shift may be a general increase in riskiness of the industry group to which the sample firm belongs. ${ }^{30}$ To examine this hypothesis further, we perform tests for beta change on the set of matched firms that was earlier used as a control for earnings forecast revisions. ${ }^{31}$ The results for the control firm sample are presented in panel $\mathrm{B}$ of Table 4 . These results indicate that the control firms do not experience any increase in (beta) risk, both when considered as a single sample and when partitioned on severity of the rating downgrade for the matching sample firms. Thus, the beta shift documented for severely downgraded firms does not appear to be due to an increase in overall risk of the industry group to which the sample firm belongs.

Two reasons may explain why the increase in equity beta is confined only to the severely downgraded firms. These are not mutually exclusive, and both are related to the orderly exit phenomenon associated with severe CP downgrades.

29. Denis and Kadlec (1994) show that studies that examine changes in beta may report erroneous results if they do not control for trading activity. We conducted tests on the difference in the volume of trade in the preevent and postevent periods used to estimate beta shifts. Both parametric and nonparametric tests showed that volume of trading was unchanged before and after the downgrade. Thus, a difference in trading activity does not appear to be the likely explanation for the beta shift. The size statistics in Table 1 indicate that our sample firms are large. Moreover, $\mathrm{CP}$ issuing firms are wellknown firms. Consequently, the additional problem of infrequent trading suggested by Denis and Kadlec (1994) is unlikely to apply here.

30. We thank the referee for this alternative explanation and for suggesting the associated test.

31. The number of observations for the control firm sample is lower than that for the sample firms due to missing security return data on CRSP. 
TABLE 4

\section{Beta Shifts Associated with Commercial Paper Rating Downgrades}

\begin{tabular}{llrr}
\hline Sample & $\begin{array}{c}\text { Number of } \\
\text { Observations }\end{array}$ & $\begin{array}{c}\text { Mean Beta } \\
\text { Shift }(\lambda)\end{array}$ & t Statistic \\
\hline Panel A: Sample firms & & & \\
Full sample & 83 & 0.055 & $1.70^{*}$ \\
Severe downgrade subsample & 31 & 0.110 & $1.84^{*}$ \\
Mild downgrade subsample & 52 & 0.038 & 0.97 \\
& & & \\
Panel B: Control firms & 76 & 0.003 & 0.09 \\
Full sample & 29 & 0.059 & 0.93 \\
Severe downgrade subsample & 47 & -0.031 & -0.73 \\
Mild downgrade subsample & & &
\end{tabular}

* Significantly greater than 0 at the 0.05 level in a one-tailed test.

$\lambda$ is the average change in beta estimated using daily stock returns over the periods [ $-300,-51]$ and $[+51,+300]$ relative to announcements of $C P$ rating downgrades.

First, as previously mentioned, CP buyers have a low tolerance for risk and view their investment as being close to cash in terms of security. If rating agencies perceive a significant increase in risk for a CP issuer, they may issue only severe rating downgrades signaling that the firm no longer meets the CP market's stringent criteria for credit quality and leading to its withdrawal from the CP market. Given this negative signal, the systematic risk of the affected firm is elevated in the equity markets. Second, if a firm depends on short-term funds to finance its working capital requirements, these requirements become greater when it faces operating problems. If the firm is driven out of the $\mathrm{CP}$ market due to a severe downgrade of its CP rating, it is deprived of this source of funds when its need is greatest. In this situation, it may replace its CP borrowings with funds from more expensive and uncertain sources leading to the increased beta that we document.

\subsection{Event Study of Commercial Paper Downgrade Announcements}

Our results thus far indicate that $\mathrm{CP}$ rating downgrades are associated with a downward revision in short-term earnings expectations for both mild and severe downgrades and an increase in systematic risk for the severe downgrades. We next examine whether these revisions in market expectations occur before the CP rating downgrades or alternatively whether they represent new information conveyed to the market by the rating change announcement.

For each firm in the sample, the Wall Street Journal Index was examined to see if the downgrade announcement was contaminated by other news announcements over the interval spanning days $[-2,0]$, where day 0 is the announcement date of the CP downgrade. Of the original sample of 97 firms, 57 were found to have informationally clean announcement dates and sufficient security return data 
TABLE 5

\section{Abnormal Returns Associated with Pure Commercial Paper Downgrades}

The results here are for the sample of 57 firms, which are drawn from the original 97 firms with CP downgrades. These 57 firms have no confounding news announcements in the period spanning days $[-2,0]$ relative to the announcement of the $\mathrm{CP}$ downgrade.

\begin{tabular}{|c|c|c|c|c|}
\hline Event Window & Mean & Median & Z Statistic & $\begin{array}{c}\text { Positive to Negative } \\
\text { Abnormal Returns }\end{array}$ \\
\hline
\end{tabular}

Panel A: Full sample

$\begin{array}{lllll}{[-50,-3]} & -0.19 \% & -0.00 \% & -0.06 & 28: 29 \\ {[-2,0]} & -1.01 \% & -0.87 \% & -2.54^{*} & 17: 40^{\star} \\ {[+1,+2]} & -0.26 \% & -0.35 \% & -0.77 & 22: 35\end{array}$

Panel $B$ : Severe downgrade subsample

$\begin{array}{lrrrc}{[-50,-3]} & 0.72 \% & 1.24 \% & 0.33 & 15: 12 \\ {[-2,0]} & -1.88 \% & -1.60 \% & -2.98^{* * *} & 5: 22^{b} \\ {[+1,+2]} & -0.04 \% & -0.54 \% & -0.33 & 9: 18\end{array}$

Panel $C$ : Mild downgrade subsample

$\begin{array}{lllll}{[-50,-3]} & -1.03 \% & -2.08 \% & -0.39 & 13: 17 \\ {[-2,0]} & -0.22 \% & -0.31 \% & -0.67 & 12: 18 \\ {[+1,+2]} & -0.47 \% & -0.35 \% & -0.75 & 13: 17\end{array}$

* Significantly different from 0 at the 0.05 level in a one-tailed test.

** Significantly different from 0 at the 0.01 level in a one-tailed test.

*** Significantly different from 0 at the 0.001 level in a one-tailed test.

${ }^{a}$ Ratio of positive to negative abnormal returns is smaller in the specified interval than in the preevent estimation period consisting of 250 days ending on day -51 in event time at the 0.01 level in a one-tailed generalized sign test.

'Ratio of positive to negative abnormal retums is smaller in the specified interval than in the preevent estimation period consisting of 250 days ending on day -51 in event time at the 0.001 level in a one-tailed generalized sign test.

available on CRSP for the analysis that follows. An event study was performed based on standardized abnormal returns (see Mikkelson and Partch [1986]), using the CRSP value weighted index return as proxy for the market return and an estimation period of 250 days ending on day -51 in event time. The results for the full sample (in panel A of Table 5) show that announcements of CP downgrades are associated with a mean price change of -1.01 percent, which is significantly negative at the 0.05 level. This result is consistent with the negative announcement effect documented by Nayar and Rozeff (1994).

The preceding analysis was replicated for subsamples formed on the severity of the downgrade. The results are shown in panel B (C) for the severe (mild) downgrade subsample. Note that the stock price reaction to mild rating downgrades is statistically insignificant, that is, the significant stock price reaction documented for the overall sample is driven entirely by the severe downgrade subsample. This shows that the information reflected in the significant earnings forecast revisions 
shown in Table 3 around mild downgrade announcements appears to be anticipated by the market prior to the downgrade date, that is, these rating changes merely confirm prior information available to the market through alternative sources. On the other hand, the increase in beta and/or decline in market expectations of earnings documented for the severely downgraded subsample constitute new information that is relevant for firm valuation, as indicated by the price response to these $\mathrm{CP}$ rating downgrade announcements. ${ }^{32}$

\section{Summary}

Strong ratings are considered by investors to be a prerequisite for participation in the commercial paper market. Although prior research has shown that stock prices respond to announcements of commercial paper rating changes, the nature of the information contained in such rating changes is unclear. This study examines whether rating downgrades are associated with changes in expectations of levels and/or riskiness of earnings. Our results are summarized next.

First, the downgrade of a firm's short-term debt rating is associated with a significant reduction in the expectation of its near term earnings. Specifically, we show that over a three-month period surrounding the rating downgrade, the revision in the Value Line earnings forecast for the first following quarter-end is significantly negative, whereas the forecast revision for the following quarter-end is also negative, albeit weaker in magnitude. These revisions in forecasted earnings occur for both severe and mild rating downgrades. We also document a tendency by analysts at Value Line to progressively revise their forecasts of quarterly earnings downward and implement two methods to control for the resulting bias. The downward revision in earnings estimates associated with $\mathrm{CP}$ downgrades is robust to these two controls. Thus, CP downgrades, in general, appear to be associated with decreases in expectations of future earnings.

Second, our examination of risk shifts indicates that firms that suffer a severe downgrade experience a statistically significant increase in beta, on average. For firms with mild downgrades, there is no evidence of an increase in beta. Changes in trading activity, infrequent trading, and increased risk of the industry group of the downgraded firms are unlikely candidates to explain the beta shifts observed. This result shows that the $\mathrm{CP}$ downgrade announcement contains information about systematic security risk which is not incorporated in the estimate of predowngrade beta. Given the "orderly exit" explanation, this has consequences for the financing of additional capital for affected firms. Specifically, severely downgraded firms will be forced to exit the $\mathrm{CP}$ market following the downgrade. To replace the $\mathrm{CP}$ borrowings that firms are unable to roll over, they will have to turn to other sources. If other debt sources are also unavailable, or more costly, the firm will have to

32. We also conducted similar tests over an expanded sample, which included events where other significant news releases occurred within the CP downgrade event window. The results of this analysis are qualitatively similar to those obtained for the clean sample and are not reported. 
issue equity. Given the increased beta, this would imply a higher cost of new equity capital, which could have negative repercussions.

Third, we examine security prices of firms around their CP downgrade dates. We find that (a) CP downgrade announcements are associated with negative stock price changes, consistent with Nayar and Rozeff (1994) and (b) this stock price reaction appears to be confined to the severe downgrade subsample. This result indicates that mild rating downgrades mainly serve to certify information already available in the market prior to the downgrade through alternative sources, whereas the lower level and/or greater variability in future earnings associated with severe downgrades conveys new valuation relevant information to the market.

\section{REFERENCES}

Abken, Peter A. 1981. "Commercial Paper." Federal Reserve Bank of Richmond Economic Review (March-April): 11-21.

Baginski, Stephen P. 1987. "Intraindustry Information Transfers Associated with Management Forecasts of Earnings." Journal of Accounting Research 25 (Autumn): 196-216.

Bartov, Eli. 1991. "Open-Market Stock Repurchases as Signals for Earnings and Risk Changes." Journal of Accounting and Economics 14 (June): 275-294.

Beaver, William H., Paul Kettler, and Myron Scholes. 1970. "The Association between Market Determined and Accounting Determined Risk Measures." The Accounting Review 45 (October): 654 682.

Brous, Peter A. 1992. "Common Stock Offerings and Earnings Expectations: A Test of the Release of Unfavorable Information." Journal of Finance 47 (September): 1517-1536.

Calomiris, Charles W., Charles P. Himmelberg, and Paul Wachtel. 1995. "Commercial Paper, Corporate Finance and the Business Cycle: A Microeconomic Perspective." Carnegie-Rochester Conference Series on Public Policy 42:203-250.

Cantor, Robert, and Frank Packer. 1995. "The Credit Rating Industry." The Journal of Fixed Income 5 (December): 10-34.

Christie, Andrew. 1987. "On Cross-sectional Analysis in Accounting Research." Journal of Accounting and Economics 9 (December): 231-258.

Comell, Bradford, Wayne Landsman, and Alan C. Shapiro. 1989. "Cross-Sectional Regularities in the Response of Stock Prices to Bond Rating Changes." Journal of Accounting, Auditing \& Finance 4 (Fall): $460-479$.

Crabbe, Leland, and Mitchell A. Post. 1994. "The Effect of a Rating Downgrade on Commercial Paper Outstandings." Journal of Finance 49 (March): 39-56.

Denis, David J., and Gregory B. Kadlec. 1994. "Corporate Events, Trading Activity, and the Estimation of Systematic Risk: Evidence from Equity Offerings and Share Repurchases." Journal of Finance 49 (December): 1787-1811.

Fons, Jerome S., and Karl Bergqwist. 1994. “Commercial Paper Defaults 1970-1993." Moody's Special Report.

Fons, Jerome S., and Andrew E. Kimball. 1992. "Defaults and Orderly Exits of Commercial Paper Issuers." Moody's Special Report.

Foster, George. 1981. "Intra-Industry Information Transfers Associated with Earnings Releases." Journal of Accouning and Economics 3 (December): 201-232.

Francis, Jennifer, and Donna Philbrick. 1993. "Analysts' Decisions as Products of a Multi-Task Environment." Journal of Accounting Research 31 (Autumn): 216-230.

Goh, Jeremy C., and Louis H. Ederington. 1993. "Is a Bond Rating Downgrade Bad News, Good News, or No News for Stockholders." Journal of Finance 48 (December): 200I-2008.

Hand, John R., Robert W. Holthausen, and Richard W. Leftwich. 1992. "The Effect of Bond Rating Changes on Bond and Stock Prices." Journal of Finance 47 (June): 733-752.

Hertzel, Michael, and Prem C. Jain. 1991. "Earnings and Risk Changes Around Stock Repurchase Tender Offers." Journal of Accounting and Econonics 14 (September): 253-274. 
Holthausen, Robert W., and Richard W. Leftwich. 1986. "The Effect of Bond Rating Changes on Common Stock Prices.” Journal of Financial Economics 17 (September): 57-89.

Kahle, Kathleen M., and Ralph A. Walkling. 1996. "The Impact of Industry Classifications on Financial Research." Journal of Financial and Quantitative Analysis 31 (September): 309-335.

Mikkelson, Wayne H., and M. Megan Partch. 1986. "Valuation Effects of Security Offerings and the Issuance Process." Journal of Financial Economics 15 (January-February): 31-60.

Nayar, Nandkumar, and Michael S. Rozeff. 1994. "Commercial Paper, Ratings and Equity Returns." Journal of Finance 49 (September): 1431-1449.

Ofer, Aharon R., and Daniel R. Siegel. 1987. "Corporate Financial Policy, Information, and Market Expectations: An Empirical Investigation of Dividends." Journal of Finance 42 (September): 889-911.

O'Brien, Patricia. 1988. "Analysts' Forecasts as Earnings Expectations." Journal of Accounting and Economics 10 (January): 53-83.

Post, Mitchell A. 1992. “The Evolution of the U.S. Commercial Paper Market Since 1980.' Federal Reserve Bulletin (December): 879-891.

Ramnath, S. 1996. "Eamings Related Information Transfers and Revisions in Earnings Expectations." Working Paper, Pennsylvania State University.

Rose, Peter S. 1985. "Money and Capital Markets." Business Publications Inc., Texas.

Schnure, Calvin D. 1994. "Debt Maturity Choice and Risk-free Assets: The 'Clientele Effect' and the Commercial Paper Market." Finance and Economics Series Discussion Paper, Washington, D.C.: Federal Reserve Board.

Shastri, Karen A. and Kuldeep Shastri. 1995. "The Information Content of Calls of Convertible Preferreds: The Evidence from Earnings Forecasts." Journal of Accounting. Auditing and Finance 11 (Fall): 607-622.

Stickel, Scott E. 1986. "The Effect of Preferred Stock Rating Changes on Preferred and Common Stock Prices." Joumal of Accounting and Economics 8 (October): 197-215.

. 1989. "The Timing and Incentives for Annual Eamings Forecasts Near Interim Earnings Announcements." Journal of Accounting and Economics 11 (July): 275-292.

1990. "Predicting Individual Analyst Earnings Forecasts." Journal of Accounting Research 28 (Autumn): 409-417.

Stigum, Marcia. 1983. The Money Market. Homewood, Ill.: Dow Jones-Irwin.

Wakeman, L. McDonald. 1984. "The Real Function of Bond Rating Agencies." In The Modern Theory of Corporate Finance, edited by Michael C. Jensen and Clifford W. Smith, Jr. New York: McGraw-Hill. 